\title{
Social Capital: Local Wisdom Community against Covid-19 (Case Study: Kampung Tangguh Malang Raya)
}

\author{
Qurnia Indah Permata Sari ${ }^{1}$, Ninda Rachmawati ${ }^{2}$, Dita Rachmawati ${ }^{3}$ \\ \{qurniaindahpermatasari@gmail.com ${ }^{1}$ \} \\ Universitas Brawijaya, Indonesia ${ }^{1,2}$ \\ STIE Koperasi Malang, Indonesia ${ }^{1,2,3}$
}

\begin{abstract}
This study aims to examine the role of social capital in Covid-19 in Malang City. This paper is based on the argument that social capital owned by the community can play a role in deciding the spread of Covid-19. The theory used in this paper is social capital can decide the spread of Covid-19. The recommendations for the government are to encourage people to consistently implement tough villages so that they can reduce the spread of Covid19 and help people affected by the pandemic.
\end{abstract}

Keywords: Social Capital, Local Wisdom, Covid-19

\section{Introduction}

Since Covid-19 was first announced on March 2, 2020, the number of people infected by Covid-19 has continued to increase. Following WHO's recommendations, the Government of Indonesia made various regulations to limit the social distance between people. However, this fact strengthens solidarity among people - assistance provided in direct aid or indirect aid. Based on Kompas.id's research, as many as $64 \%$ of respondents increasingly care for others during the Covid-19 pandemic [1].

Previous studies on social capital over time pandemic Covid-19, discusses some of the following, First, the impact of social capital [2][3], Second, the effect of social capital on the isolated [4], Third, how to design social capital to deal with Covid-19 [5]. In contrast to previous studies, this study will examine the role of social capital in dealing with Covid-19. Kristin said that with the existence of high social capital in a society, the death rate due to Covid-19 is lower, and the level of mobility can go down [2].

This research is intended to complement the shortcomings of the existing study by carefully mapping the role of each actor in Covid-19 prevention in Kampung Tangguh, explaining how social capital can work in Kampung Tangguh amid restrictions on social distance imposed by the government for prevent the spread of Covid-19 and explain the impact of the existence of Kampung Tangguh in the prevention of Covid-19.

This paper is based on the argument that local wisdom owned by the community can decrease the spread of Covid-19. Social capital in Malang is known as Kampung Tangguh. Kampung Tangguh can support government policies in preventing the prevention of Covid- 19 and that as a local ability to deal with various security problems and regional defenses such as the Covid-19 disaster. This research uses a qualitative approach with literature review. Data 
collection methods used are online newspaper and documentation. Analysis of the data used is pattern matching.

The establishment of Kampung Tangguh started with the idea of the community to make their villages ready to face Covid-19, not just to close the town without any preparation and to harm the survival of residents and various other negative impacts. Each actor in a resilient village has a dominant role in deciding Covid-19. The characters are as follows: First, mothers who are members of the PKK (Family Welfare Empowerment) cadre and Dasa Wisma can manage food barns, Second, Posyandu cadres or Disaster Response Family Cadres can handle Covid-19, Third, Babinsa or village security guard can operate a thermometer to measure the body temperature of residents who enter the village and to socialize residents who enter the town to comply with the Covid-19 protocol, Fourth, RW-level (citizens Association) local artists can broadcast information about covid-19 so that residents can better understand the Covid-19, Fifth, villagers have an understanding related to Covid-19, Sixth, the city government provides both material and non-material assistance in the implementation of resilient villages.

If residents can actively participate, it will be able to trigger the growth of citizen awareness and collective discipline to deal with a disaster, especially Covid-19. This discipline will be reflected in citizens' daily lives during their activities without the need to be encouraged to comply with the health protocol recommended by the government. The government can also save the budget because the low costs for handling Covid-19 can be minimized by involving the community.

This paper is based on the argument that social capital owned by the community can play a role in deciding the spread of Covid-19. Social capital in Malang is known as Kampung Tangguh. the data shows that the rate of transmission in greater Malang before the large-scale restriction is three, whereas after the large-scale restriction accompanied by the resilient village, the rate of transmission in greater Malang is 1. Besides that, with the existence of Kampung Tangguh, one of the Villages in Malang Regency which is the Covid-19 Distribution Area for the first time now there is no positive patient record of Covid-19.

\section{Literature Review}

\subsection{Social Capital}

According to Fukuyama, social capital is an ability that comes from trust in a community [6]. Social Capital according to Putnam includes social relations, social norms, and trust [6]. According to Coleman, social capital has characteristics that are an aspect of social structure and facilitates individual actions in the social structure [6]. Social Capital is something that can solve all the problems that exist in society today [7]. Social relations between parties are created due to a series of networks and the similarity of values in the system. Social capital is related to the understanding of the community or community that enables the formation of networks of cooperation to solve problems to improve the quality of life and make better changes. As James Coleman (1988) said, social capital as a structure of relationships between individuals can create new values. Social capital is an understanding, norms, rules, and expectations about patterns of interaction carried out by individuals carrying out their daily activities [8].

Social capital is something that can solve all the problems that exist in society today [7]. There are three types of social capital, namely bridging social capital, linking social capital, and bonding social capital. bonding social capital is social capital that adheres firmly and comes 
from internal communities such as beliefs, local wisdom norms, organizations, local associations. linking capital social is social capital in the form of the formation of communities within the community to overcome problems faced by the community. social capital linking is social capital in the cooperation between community levels in the community with stakeholders or the government. These three types of social capital are essential to overcome various problems in a region [9].

\subsection{Kampung Tangguh}

Kampung Tangguh is initiated by Mangku Purnomo. Mangku believes there must be mutual cooperation efforts starting from the village or grassroots level. Mangku and Kol (Inf) Zainuddin, the commander of Korem 083 Baladika Jaya, made a conceptual framework assisted by UB experts in the fields of medicine, public health, food security, economics, politics as well as law, and defense and security.

After it was considered mature enough, the concept of establishing a resilient village was then tried out in several areas, such as the circumference of the campus and Cempluk villages. After the simulation, a strong village PSBB manual was compiled Tangguh Kampung itself has 7 toughness criteria, namely tough logistics, tough human resources (HR), resilient information, resilient health, tough security and order, tough culture, and strong psychologically. Currently, more than 100 villages have been installed with various resilience regarding how the crisis and the impact of the spread of Covid-19. The program has been well-known in cities and districts in East Java, and even in several villages outside Java.

Mangku and the UB Covid-19 Task Force team continue to educate residents of the surrounding villages of UB about monitoring the bodies of patients infected with the corona virus in Kalisongo Village, Dau District, Malang Regency. Kampung Tangguh is the ability of local communities to deal with various security disturbances and regional defenses that are useful inward off multiple disasters, natural emergencies, and non-natural disasters. Kampung Tangguh can help the community at the local level to organize all of their resources to be more effective in dealing with natural and non-natural disasters, especially Covid-19. Disaster Resilient Village Development is an effort to reduce the risk of community-based accidents.

Kampung Tangguh does not aim to build new structures but utilizes existing structures to deal with disasters, especially Covid-19. Existing structures are given additional toughness skills to deal with natural and non-natural disasters. Utilization of the existing structure aims not to take too much time to build new personnel at the local level to deal with specified emergencies. Involving women citizens in disaster management can also be very helpful, primarily related to food or health needs. Volunteers needed for resilient villages include people who have high social life, are active in village activities, communicate well with other residents, control residents, know the village well, and know about physical and mental health.

Kampung Tangguh has seven pillars in dealing with Covid-19 disasters, First, resilient food and energy, Second, resilient human resources, Third, resilient safe and orderly, Fourth, resilient information, Fifth, resistant psychology, Sixth, resilient culture, Seventh, robust health. The objectives of the Kampung Tangguh in dealing with natural and non-natural disasters are as follows; First, if a prolonged accident will potentially lead to riots, economic and social losses, Second, it can be used as a pattern for dealing with disasters based on togetherness and social engineering, Third, limitations the state apparatus so that anticipation is taken to deal with emergencies. Each citizen has their respective duties and may not concurrently hold more than one strength to be effective. 


\section{Research Method}

This research uses a qualitative approach with literature review. Data collection methods is literature review. Literature Review used are online newspaper and documentation. Analysis of the data used is pattern matching. This research is intended to complement the shortcomings of the existing study by how social capital can work in Kampung Tangguh amid restrictions on social distance imposed by the government for prevent the spread of Covid-19 and explain the impact of the existence of Tangguh Village in the prevention of Covid-19.

\section{Result and Findings}

The establishment of Kampung Tangguh started with the idea of the community to make their villages ready to face Covid-19, not just to close the town without any preparation and to harm the survival of residents and various other negative impacts. Each actor in a resilient village has a dominant role in deciding Covid-19. The characters are as follows: First, mothers who are members of the PKK (Family Welfare Empowerment) cadre and Dasa Wisma can manage food barns, Second, Posyandu cadres or Disaster Family cadres can handle Covid-19, Third, Babinsa or village security guard can operate a thermometer to measure the body temperature of residents who enter the village and to socialize residents who enter the town to comply with the Covid-19 protocol, Fourth, Citizens Association local artists can broadcast information about Covid-19 so that residents can better understand the Covid-19, Fifth, villagers have an understanding related to Covid-19, Sixth, the city government provides both material and non-material assistance in the implementation of resilient villages.

This paper is based on the argument that social capital owned by the community can play a role in deciding the spread of Covid-19. Social capital in Malang is known as Kampung Tangguh. The data shows that the Rate of Transmission in Greater Malang before the LargeScale Restriction is three, whereas after the Large-Scale Restriction accompanied by the Resilient Village, the Rate of Transmission in Greater Malang is 1. Besides that, with the existence of Kampung Tangguh, one of the Villages in Malang Regency which is the Covid-19 Distribution Area for the first time now there is no positive patient record of Covid-19.

If residents can actively participate, it will be able to trigger the growth of citizen awareness and collective discipline to deal with a disaster, especially Covid-19. This discipline will be reflected in citizens' daily lives during their activities without the need to be encouraged to comply with the health protocol recommended by the government. The government can also save the budget because the low costs for handling Covid-19 can be minimized by involving the community. Social capital is something that can solve all the problems that exist in society today [7]. There are many communities that emerged during the pandemic.

There are many communities that emerged during the pandemic, First, Pangan Malang Community (Tangan Malang Community). This community emerged in April 2020, when people had to stay at home more often. An idea emerged to use the community's sleeping land on Kendalsari, Lowokwaru, Sukun, Malang City. The residents' sleeping land is managed into a garden. Starting from tomatoes, mustard greens, Telang flowers, kale, and many other vegetable crops. Support also comes from other communities. They give kale and mustard greens to the local people while doing education and socialization.

Second, Habis Gelap Terbitlah Terang Community. These volunteers are a combination of community organizations in Malang Raya, namely Anak Negeri, AMATI, LINKSOS, Omah 
Gotong Royong, Tunggulwulung Cultural School, Online Ojek Community and others. Regarding the collection and distribution of this community in collaboration with several members of the Online Ojek community in Malang Raya. This is so that it can help the economy of the online motorcycle taxi community which is also affected by the Covid-19 outbreak. Distributed assistance is in the form of foodstuffs (basic needs, instant noodles, side dishes and so on).

Three, Peduli Malang Community, this community collects social funds from its members through their Facebook group account. Then distribute directly to people who need help and are affected by the Covid-19 pandemic. Assistance is distributed directly to online motorcycle taxis on the road, pedicab drivers and hawkers selling their wares around Ijen. This community then uploads the pictures on the social media of the community to publish the distribution activity.

Kampung Tangguh does not aim to build new structures but utilizes existing structures to deal with disasters, especially Covid-19. Existing structures are given additional toughness skills to deal with natural and non-natural disasters. Utilization of the existing structure aims not to take too much time to build new personnel at the local level to deal with specified emergencies. Involving women citizens in disaster management can also be very helpful, primarily related to food or health needs. Volunteers needed for resilient villages include people who have high social life, are active in village activities, communicate well with other residents, control residents, know the village well, and know about physical and mental health.

Kampung Tangguh is initiated by Mangku Purnomo. Mangku believes there must be mutual cooperation efforts starting from the village or grassroots level. Mangku and Kol (Inf) Zainuddin, the commander of Korem 083 Baladika Jaya, made a conceptual framework assisted by UB experts in the fields of medicine, public health, food security, economics, politics as well as law, and defense and security.

After it was considered mature enough, the concept of establishing a resilient village was then tried out in several areas, such as the circumference of the campus and Cempluk villages. After the simulation, a strong village PSBB manual was compiled Tangguh Kampung itself has 7 toughness criteria, namely tough logistics, tough human resources (HR), resilient information, resilient health, tough security and order, tough culture, and strong psychologically. Currently, more than 100 villages have been installed with various resilience regarding how the crisis and the impact of the spread of Covid-19. The program has been well-known in cities and districts in East Java, and even in several villages outside Java.

Kampung Tangguh carries the spirit of mutual cooperation as seen in First, Kampung Tangguh Mandiri (KTM) RW 5, Kelurahan Purwantoro, Malang City. People in need can take rice and those who are able can donate. People in need can take rice and those who are able can donate. The village is also preparing isolation houses for ODP/PDP/even people who are allegedly infected with Covid-19. The tough village also has a team who have been trained to cover the body of Covid-19.

Second, Kampung Cempluk has several innovations in dealing with Covid-19 as listed in the seven strengths, namely logistics, human resources, resilient health, resilient information, security, order, culture and psychology. Kampung Cempluk has a food barn that can help meet the logistical needs of 1,560 residents divided into 400 families. Residents also get socialization to deal with the Covid-19 Pandemic. There is a provision of a thermal gun, wearing masks and a place to wash hands with running water.

Kampung Tangguh Narubuk has a RW level food barn which is operated by PKK mothers and local residents to help residents affected by Covid-19. This food barn receives basic food assistance from donors to be distributed to affected residents. The food barn provides basic necessities ranging from rice, cooking oil to sugar. The food storage stock there is said to last 
for the next three months. Not only about the food barn, in this tough village, residents are also invited to be aware of being vigilant in facing the Covid-19 pandemic. In every corner of Narubuk village, there is a place for washing hands with running water and also using soap. Its residents also wear masks in an orderly manner when leaving the house. Village officials were also active in reminding residents not to leave the house except in urgent circumstances.

Tangguh Kampung itself has 7 toughness criteria, namely tough logistics, tough human resources (HR), resilient information, resilient health, tough security and order, tough culture, and strong psychologically. Currently, more than 100 villages have been installed with various resilience regarding how the crisis and the impact of the spread of Covid-19. The program has been well-known in cities and districts in East Java, and even in several villages outside Java.

\section{Conclusion}

This paper is based on the argument that social capital owned by the community can play a role in deciding the spread of Covid-19. The theory used in this paper is social capital can decide the spread of Covid-19. The recommendations for the government are to encourage people to consistently implement tough villages so that they can reduce the spread of covid-19 and help people affected by the pandemic.

Kampung Tangguh does not aim to build new structures but utilizes existing structures to deal with disasters, especially Covid-19. Existing structures are given additional toughness skills to deal with natural and non-natural disasters. Utilization of the existing structure aims not to take too much time to build new personnel at the local level to deal with specified emergencies. Involving women citizens in disaster management can also be very helpful, primarily related to food or health needs. Volunteers needed for resilient villages include people who have high social life, are active in village activities, communicate well with other residents, control residents, know the village well, and know about physical and mental health.

\section{References}

[1] S. Agustina, "Menjaga Solidaritas, Mencegah Konflik akibat Covid-19," www.kompas.id, 2020.

[2] A. Kristin, "Social Capital and the Spread European Countries," 2020.

[3] R. Durante, L. Guiso, and G. Gulino, "Asocial Capital: Civic Culture and Social Distancing during COVID-19,” SSRN Electron. J., no. 1, 2020.

[4] H. Xiao, Y. Zhang, D. Kong, S. Li, and N. Yang, "Social capital and sleep quality in individuals who self-isolated for 14 days during the coronavirus disease 2019 (COVID-19) outbreak in January 2020 in China," Med. Sci. Monit., vol. 26, pp. 1-8, 2020.

[5] J. Sloan, "Designing the Civic Commons: How Design can Foster Social Capital in Civic Spaces in the Context of Urban Sprawl," vol. 2507, no. 1, pp. 1-9, 2020.

[6] R. Kimbal, Modal Sosial dan Ekonomi Industri Kecil Sebuah Studi Kualitatif. Yogyakarta: Deepublish, 2015.

[7] A. Portes, "Social capital: Its origins and applications in modern sociology," Knowl. Soc. Cap., pp. 43-68, 2009.

[8] G. Prayitno, A. Subagiyo, S. A. Rusmi, and E. F. Febriana, Perencanaan Desa Terpadu Modal Sosial dan Perubahan Lahan. Magetan: CV. AE Media Grafika, 2019.

[9] M. A. Marfai, E. Rahayu, and A. Triyanti, Peran Kearifan Lokal dan Modal SOsial dalam Pengurangan Risiko Bencana dan Pembangunan Pesisir Integrasi Kajian Lingkungan, Kebencanaan dan Sosial Budaya. Yogyakarta: Gadjah Mada University Press, 2018. 